\title{
Rozalia Słodczyk \\ Znaczenie listu w malarstwie XVII i XVIII wieku oraz w ówczesnej powieści epistolarnej
}

\begin{abstract}
Słodczyk Rozalia, Znaczenie listu w malarstwie XVII i XVIII wieku oraz w ówczesnej powieści epistolarnej [The importance of the letter in the 17th and 18th century painting and in the epistolary novel of that time]. „Przestrzenie Teorii” 12. Poznań 2009, Adam Mickiewicz University Press, pp. 165-191. ISBN 978-83-232-2077-0. ISSN 1644-6763.

The aim of this paper is to analyse and interpret the importance of the letter in the 18th century epistolary novel and the 17th and 18th century painting. The article presents properties and functions of the letter that made it attractive to the literature and painting of that time. The focus is also on social and cultural context relevant to the discussed matter. Furthermore, the paper examines the form and content of the novel and painting in question, including the specific ways and consequences of the employment of the letter by these disciplines. Finally, the problem of illusionism is considered.
\end{abstract}

\section{List w XVII i XVIII wieku a kontekst społeczno-kulturowy}

Stulecia XVII i XVIII to okresy, w których list znajduje się w centrum zainteresowania, są one uważane za złote wieki listu zarówno ze względu na popularność epistolografii w codziennej praktyce użytkowej, jak i inspirowanie się listami przez malarstwo oraz literaturę. Fenomen ów można pełniej poznać i zinterpretować, uświadamiając sobie znaczenie sfery pozaliterackiej i pozaplastycznej, zatem kontekstu społecznego i kulturowego.

Listy były formą wypowiedzi pisemnej cenioną za możliwość stosunkowo szybkiego przekazywania informacji bezpośrednio do adresata, $\mathrm{w}$ formie i treści ustalonej przez nadawcę, dzięki temu nie deformował ich i nie pozbawiał tajemnicy np. ustny przekaz posłańca. Pisanie listów w XVII i XVIII wieku było praktyką niemal powszechną, cieszącą się wielkim zainteresowaniem, było ulubionym zajęciem nie tylko wąskiej grupy ludzi znamienitych i wykształconych - pisali właściwie wszyscy, do tego niezmiernie często i bardzo dużo. Można w zasadzie mówić o modzie na listy, o panującym kulcie listu. Powstawały oczywiście listy oficjalne i praktyczne, ale szczególne znaczenie miał rozwój epistolografii 
prywatnej i intymnej ${ }^{1}$, co wiązało się z prowadzonym życiem towarzyskim, pogłębionym życiem duchowym oraz znaczeniem przypisywanym stosunkom rodzinnym i przyjacielskim ${ }^{2}$. Listy zapewniały kontakt mimo odległości, dawały możliwość zbliżenia oraz namiastkę prywatności, a nawet intymności oddalonym od siebie osobom, w konsekwencji pozwalały na swego rodzaju uobecnienie kogoś nieobecnego, a drogiego, na poczucie bliskości psychicznej i duchowej mimo dystansu przestrzennego. Fascynowały również swoją mocą dyskretnej komunikacji dotyczącej spraw osobistych, dlatego też holenderski XVII-wieczny teoretyk sztuki Karel van Mander w swojej Schilder-boeck nazwał listy cichymi posłańcami, dzięki którym ludzie mogą mówić do siebie, a wymianę korespondencji nazywano rozmową na papierze, konwersacją piór bądź konwersacją na odległośćc

Od czasów nowożytnych w listach widziano obraz duszy, wnętrza piszącego, a było to szczególnie ważne dla korespondencji prywatnej bliskich sobie osób (towarzyskiej, rodzinnej, przyjacielskiej bądź miłosnej). Piszący mówił bowiem w listach o sobie, o wydarzeniach, które go dotyczyły, o swoich działaniach, opiniach i uczuciach, przedstawiał $\mathrm{w}$ ten sposób siebie innym, ukazywał bezpośrednio swoją indywidualność, subiektywność, a także prywatność codziennego życia wraz z jego obowiązkami i przyjemnościami oraz intymność życia emocjonalnego ${ }^{4}$. Prywat-

${ }^{1}$ Listy konwencjonalno-towarzyskie i przyjacielsko-intymne na szeroką skalę zaczęły się pojawiać w II połowie XVI wieku, ale królowały w XVII i XVIII wieku. Zob. S. Skwarczyńska, Cel praktyczny listu, [w:] taż, Teoria listu, Lwów 1937, s. 91-115. W tym czasie „poszerza się i demokratyzuje krąg korespondentów, niespotykane przedtem znaczenie osiąga korespondencja osobista”. M. Czermińska, Pomiędzy listem a powieścia, „Teksty” 1975, z. 4 (22), s. 32.

2 Zob. S. Skwarczyńska, Teoria listu, dz. cyt., s. 109-110. Kulturze listu w XVIII wieku poświęcona jest książka Roberta Vellusiga, Schriftliche Gespräche. Briefkultur im 18. Jahrhundert, Wien-Köln-Weimar 2000 (zob. zwłaszcza rozdz. Einleitung: Buchdruck und Aufklärung poświęcony pragnieniu komunikacji, wymianie informacji, kulturze pisma i listu oraz rozdz. Der Brief als Medium von Intimität. Strukturelle und funktionale Aspekte des Freundschaftbriefes skupiający się na korespondencji przyjaciól, aktywności towarzyskiej, znaczeniu intymności).

3 S. Alpers, The Art of Describing. Dutch Art in the Seventeenth Century, Chicago 1983, s. 200. Zob. też: T.O. Beebee, Epistolary Fiction in Europe 1500-1850, Cambridge 2006, s. 1. Od Madame de Sévigné pochodzi określenie „la correspondance est une conversation à distance". Zob. Lettres de M-me de Sévigné. Précédées d'une notice sur sa vie et du traité sur le style épistolaire de Madame de Sévigné par M. Suard, Paris 1861, s. 32. Cyt. za: S.A. Aleksandrowicz, Preromantyczne listowanie jako forma ekspresji uczuć, „Pamiętnik Literacki” 1993, z. 2, s. 72.

${ }^{4}$ Oczywiście mówimy tu o listach prywatnych, jeśli bowiem list dotyczył spraw bardziej oficjalnych, konwencjonalnych i skierowany był do znajomych raczej niż rodziny czy też przyjaciół, zmieniał się cel korespondencji i okoliczności jej pisania, więc tym samym 
ność takich listów była niejako podwójna - dotyczyła przekazywanej treści i formy, w jakiej to robiła (indywidualny styl, ekspresja wypowiedzi, charakter pisma, wygląd listu etc.), ale też wiązała się z tym, że zasadniczo tylko jedna osoba była uprawniona do ich odbioru, do uczestniczenia w życiu kogoś innego i do informowania go z kolei o swoim ${ }^{5}$.

Znaczenie listu w tym czasie wiąże się też z sytuacją społeczną i gospodarczą oraz kulturową ówczesnej Europy. Wpływ na popularność listów miała wzrastająca liczba osób umiejących pisać i czytać6, które musiały lub chciały prowadzić korespondencję zawodową i prywatną, a także stosunkowa łatwość przesyłania listów, głównie dzięki rozwijającemu się systemowi usług pocztowych. Fascynacja listami była tak duża, że pisano je nawet $\mathrm{w}$ formie rozrywki towarzyskiej albo sposobu wyrażania siebie, notowania zdarzeń ze swojego życia. Przywiązywano wagę nie tylko do materialnej strony listu, jego estetyki, lecz także do odpowiedniej kompozycji i stylu wypowiedzi. Umiejętność właściwego tworzenia listów była porównywana do mistrzowskiego opanowania sztuki konwersacji, a obie sprawności jawiły się jako właściwe wyrafinowanym członkom wyższej klasy, stawały się świadectwem wykształcenia, wychowania i obycia towarzyskiego. Piszący listy mogli korzystać z nauki pod okiem specjalistów ${ }^{7}$ oraz z powstających podręczników, w których można

list stawał się mniej nasycony prywatnością, indywidualnością, swobodą i emocjonalnością, wtłaczany był w ramy konwencji na poziomie formy, stylu i treści.

${ }^{5}$ Listy były także istotne jako same przedmioty, cenne w swej materialności jako ślad innej osoby, w pewnym sensie jako jej namiastka, co było widoczne w wypadku korespondencji rodzinnej, przyjacielskiej i szczególnie miłosnej, a czego odbicie znajdziemy w powieści w listach oraz malarstwie - listy są całowane, wylewa się na nie łzy, drze się je, trzyma na piersi, wreszcie stają się przedmiotem pożądania (z różnych powodów emocjonalnych, społecznych, politycznych itd.), a nawet bywają kradzione. O liście zwracającym na siebie samego uwagę pisze Beebee w rozdziale Self-reflexive letters, [w:] T.O. Beebee, Epistolary Fiction in Europe 1500-1850, dz. cyt., s. 48-75.

${ }^{6}$ Między XVI a XVIII wiekiem w całej Europie nastąpił duży wzrost liczby osób umiejących się podpisać. Duże wskaźniki alfabetyzacji zaobserwowane zostały w Europie Północnej i Północno-Zachodniej, na których to terenach w końcu XVIII wieku piśmiennych było 60-70\% mężczyzn i około $40 \%$ kobiet. W pozostałej części Europy stopień alfabetyzacji był niższy, jednak trudno jest go dokładnie określić ze względu na mniejszą skalę badań. Zob. P.C. Sutton, Love Letters: Dutch Genre Paintings in the Age of Vermeer, [w:] Love Letters: Dutch Genre Paintings in the Age of Vermeer, kat. wyst., red. P.C. Sutton, L. Vergala, A.J. Adams, London 2003; R. Chartier, Stosowanie pisma, [w:] Historia życia prywatnego. Tom 3 - Od renesansu do oświecenia, red. R. Chartier, przeł. M. Zięba, K. Osińska-Boska, M. Cebo-Foniok, Wrocław 2005.

${ }^{7}$ Istniał osobny zawód sekretarza, który uczył tego, co wiązało się z pisaniem listów - od ostrzenia pióra i mieszania atramentu, przez kaligrafię, do właściwych sposobów adresowania i komponowania różnych typów listów. Zob. R. Chartier, Stosowanie pisma, dz. cyt., s. 134; P.C. Sutton, Love Letters..., dz. cyt., s. 32. 
było znaleźć wzory rozmaitych typów listów (spośród wielu książek tego typu największy sukces odniósł Le secrétaire à la mode Jeana Pugeta de la Serre'a, wydany po raz pierwszy w 1630 roku, a mający kilkadziesiąt wydań w wielu językach do końca wieku ${ }^{8}$ ). Istniała też możliwość doskonalenia się w kaligrafii, której uczono w szkołach, poświęcano podręczniki i w zakresie której urządzano konkursy9 ${ }^{9}$

Z tymi zjawiskami wiązało się też rodzące się zainteresowanie człowiekiem jako jednostką, indywidualnym, subiektywnym i autonomicznym podmiotem, a także fascynacja jego życiem wewnętrznym, uczuciowym i mentalnym. Również łączyło się z nimi znaczenie, jakie przypisywano analizie i introspekcji oraz poszukiwanie psychologicznych motywacji zachowań człowieka. Wszystko to uwypukliły ówczesne koncepcje filozoficzne, takie jak empiryzm brytyjski (Locke, Hume), etyka Shaftesbury'ego oraz poglądy Rousseau związane ze stanem naturalnym i rolą uczucia, znalazło to odzwierciedlenie również w formującym się sentymentalizmie i romantyzmie. Nacisk kładziony był na związki osobowe jednostek (rodzinne, przyjacielskie, towarzyskie, miłosne), ale również na znaczenie więzi społecznych oraz poczucia harmonii z przyroda. Zainteresowano się codziennym życiem człowieka, zwłaszcza jego sferą prywatną, a nawet intymną, zwykłymi czynnościami i rozrywkami, którym oddawali się ludzie, wreszcie ich otoczeniem przestrzennym oraz przedmiotowym ${ }^{10}$. Pojawienie się listu jako motywu malarskiego oraz

${ }^{8}$ Pisanie listów o charakterze osobistym lub nawet intymnym było pierwotnie traktowane jako rozrywka wyższych klas we Francji, gdzie po raz pierwszy skodyfikowano ich zasady - znalazły się one w popularnych $\mathrm{w}$ XVI wieku podręcznikach: L'instruction de bien et parfaitement écrire Jeana Lemoyne'a z 1550 roku oraz zwłaszcza Lettres missives et familières Etienne'a du Troncheta, po raz pierwszy wydanych w 1569 roku, a w czasie kolejnych 15 lat drukowanych jeszcze 30 razy, dotyczących głównie korespondencji prywatnej. Podręczniki tego rodzaju były bardzo popularne, czytane nie tylko we Francji, ale też przez Anglików czy też Holendrów.

${ }^{9}$ Karel van Mander nazwał kaligrafię sztuką dziesiątej muzy, a w swojej antologii wierszy holenderskich autorów pod tytułem Den Nederduytschen Helicon z 1610 roku obok poetów umieścił profesjonalnych kaligrafów. Byli oni wówczas czczeni w poezji, malowanych i rytych portretach, a próbki ich talentu często wisiały na ścianie obok obrazów. Zob. A.J. Adams, Discipling the Heart, [w:] P.C. Sutton, Love Letters..., dz. cyt., s. 66 oraz 69.

10 Zob. m.in. Ch. Taylor, Źródła podmiotowości. Narodziny tożsamości nowoczesnej, przeł. M. Gruszczyński, O. Latek, A. Lipszyc, A. Michalak, A. Rostkowska, M. Rychter, Ł. Sommer, Warszawa 2001; J. Płuciennik, Indywidualizm, nowożytność $i$ oświecenie, [w:] tegoż, Nowożytny indywidualizm a literatura. Wokót hipotez o kreacyjności Edwarda Younga, Kraków 2006; Historia życia prywatnego, dz. cyt., (m.in. rozdz. N. Castan, Sfera prywatna a życie osobiste oraz O. Ranum, Ostoje intymności); T. Kostkiewiczowa, Klasycyzm, sentymentalizm, rokoko. Szkice o pradach literackich polskiego Oświecenia, Warszawa 1975; J. Kleiner, Sentymentalizm i preromantyzm, Kraków 1975. 
powieści w listach pozostaje w bezpośrednim związku z sytuacją społeczną i kulturową omawianego okresu, która wyjaśnia ów fenomen, a zarazem której część on stanowi.

\section{Malarstwo z motywem listu}

Holenderscy artyści byli pierwszymi, którzy podjęli w swoich pracach temat listów i jedynymi spośród malarzy europejskich, którzy poświęcili owemu motywowi tak wiele obrazów. Królował on tu w XVII wieku, z końcem tego stulecia przestał być popularnym motywem, ale w XVIII wieku odżył w innym kręgu kulturowym - przede wszystkim w dziełach francuskich, a także, choć na o wiele mniejszą skalę, w angielskich i włoskich ${ }^{11}$. Pojawiał się też później, ale rzadko i raczej przypadkowo, tak że nie sposób wskazać środowisk bądź dekad, w których byłby szczególnie popularny, a dzieła takie nie miały większego znaczenia dla późniejszej sztuki.

List jako motyw w malarstwie dominował wówczas, gdy jednocześnie wielkie zainteresowanie budził w literaturze w całej niemal Europie, gdy zaczęto tworzyć i namiętnie czytać utwory literackie wykorzystujacee formę listu. Powieść w listach rozwijała się bowiem w XVII, a zwłaszcza XVIII wieku (dla malarstwa z motywem listu z kolei bardziej owocny niż XVIII był wiek XVII), natomiast w okresie późniejszym można ją spotkać o wiele rzadziej, jej treść wówczas niekoniecznie dotyczy związków emocjonalnych, zwłaszcza miłosnych, a forma stanowi przykład stylizacji na powieść epistolarną. Zatem po dwóch wiekach gorącej, niemal szalonej miłości do listu obie dziedziny sztuki przestają się nim fascynować, niemal zapominają o nim, podobnie zresztą czytelnicy i widzowie. Wiąże się to ze zmianą zainteresowań i gustu odbiorców, ze zmianą kontekstu społecznego i kulturowego.

Najliczniejsze przedstawienia listów znajdujemy w holenderskim malarstwie rodzajowym ${ }^{12}$. Pojawiały się one jednak również $\mathrm{w}$ portre-

11 Trzeba zaznaczyć, że nie można wiązać występowania motywu listu w malarstwie XVIII wieku z bezpośrednim wpływem malarstwa holenderskiego, zwłaszcza że w XVIII wieku pojawia się on o wiele rzadziej i nie powtarza schematów znanych z obrazów holenderskich. Podobieństwo oparte na pojawieniu się tego samego tematu związane jest raczej ze wspólnym kontekstem kulturowym, który wyjaśnia wystarczająco i przekonująco występowanie listu na obrazach francuskich, a także angielskich i włoskich, podobnie jak uzasadnia występowanie tego motywu w sztuce holenderskiej. Zob. A. Pieńkos, Holandyzm $w$ malarstwie francuskim XVIII $w$. W oczekiwaniu na synteze, „Ikonotheka” $\mathrm{nr} 7$, Warszawa 1995.

${ }^{12}$ List przedstawiali na swych obrazach głównie: Dirck Hals, Pieter Codde, Willem Duyster, Gerard ter Borch, Frans van Mieris, Gerard Dou, Caspar Netscher, Gabriel 
tach oraz w martwych naturach. W portretach obecność listów wynikała z samej ich popularności, także z tego, że były atrybutem wskazującym na wykształcenie przedstawionej osoby albo, jeśli pojawiał się na nich adres bądź nazwisko, identyfikowały przedstawiona postać. Z kolei list w martwych naturach, oprócz chęci pokazania przez malarza swojego talentu, kunsztu i doskonałości technicznej, przejawiających się w dążeniu do jak najwierniejszego naśladownictwa rzeczywistości, służył też niekiedy zbudowaniu przesłania, m.in. egzystencjalnego i moralnego, zwłaszcza przez umieszczone na nim inskrypcje lub dedykacje ${ }^{13}$. W scenach rodzajowych list nie ma tak jasnego znaczenia, jego treść pozostaje widzowi najczęściej niedostępna, ale można się jej domyślać z reakcji postaci, z ich mimiki i gestów, z okazywanych przez nie emocji, a także na podstawie otoczenia, w którym odnajdujemy osoby, czynności, zwierzęta i przedmioty o wyraźnym i utrwalonym znaczeniu ${ }^{14}$ lub wreszcie na podstawie znajomości form i funkcji listu w ówczesnej kulturze. Wszystko to pozwala zrozumieć i zinterpretować przedstawioną scenę, dopełnia i uwydatnia bowiem treść obrazu oraz podpowiada, co jest tematem listu będacego bohaterem sceny, zatem w konsekwencji malarstwo wykorzystujące motyw listu nie jest dziedziną, która zamyka przed nami prywatne życie i uczucia postaci ${ }^{15}$.

Dominującą treścią przedstawień w obrazach rodzajowych $\mathrm{z}$ motywem listu są sceny z codziennego życia, najczęściej prywatne, rozgrywające się we wnętrzach domowych. Bohaterami może być kilka osób - członków rodziny lub przyjaciół - bądź tylko dwie, małżonkowie, kochankowie, zalotnicy, jak również może zostać ukazana tylko jedna postać, która w samotności zajmuje się swoimi sprawami, spełnia obowiązki albo oddaje się przyjemnym rozrywkom wolnego czasu. Postaci te wykonują różne czynności związane z listem: piszą, czytają, wysyłają go, otrzymują lub dyktują. Przedstawione zostają zarówno kobiety, jak i mężczyźni - te pierwsze umieszczane są wyłącznie w sferze prywatnej,

Metsu, Pieter de Hooch, Jan Vermeer, Jan Steen, Adriaen van Ostade. Zob. katalog wystawy Love Letters oraz Masters of Seventeenth-Century Dutch Genre Painting, kat. wyst., red. P.C. Sutton, Ch. Brown, Philadelphia 1984.

13 P.C. Sutton, Love Letters..., dz. cyt., s. 15.

14 Chodzi m.in. o znaczenie służących, stręczycielek, żołnierzy, doktorów, zwierząt (np. psa), pustych krzeseł, łóżek, owoców, map, przedstawionych w obrazie obrazów, a także czynności - takich jak muzykowanie, picie wina, uczestniczenie w grach, szycie.

15 Dlatego nietrafna wydaje się uwaga Svetlany Alpers, której zdaniem istnieje różnica między światem literatury a przestrzenią malarstwa posługującymi się listem: „while the novel makes the world of private passions accessible, the Dutch painters depict women absorbed in the perusal of a correspondence that is closed to us. It is cleary represented as an isolating affair". S. Alpers, The Art of Describing..., dz. cyt., s. 193. 
intymnej, tzn. domowej lub towarzyskiej16, ci drudzy znajdują się nie tylko w otoczeniu prywatnym, lecz także, choć rzadziej, oficjalnym i zawodowym - w gabinetach oraz miejscach pracy (są to osoby związane $\mathrm{z}$ nauką, dyplomacją, handlem, rzemiosłem, a także prawnicy, notariusze, oficerowie, zwykli żołnierze oraz posłańcy). Przedstawieniami najbardziej interesującymi pod względem treści i ikonografii są jednak te, które ukazują mężczyzn i kobiety w sytuacjach nieoficjalnych, przy czym najczęstsze, a zarazem najbardziej fascynujące są nasycone uczuciowością obrazy pokazujące intymny świat kobiet, eleganckich, zamożnych, pięknych i wykształconych dam albo pań lekkich obyczajów. Poszczególne elementy namalowanej sceny przekonują, że pojawiające się listy najczęściej dotyczą spraw związków emocjonalnych między członkami rodziny, przyjaciółmi, a zwłaszcza między zakochanymi, więc odnoszą się przede wszystkim do miłości, ujawniają dominację uczuciowości oraz zmysłowości.

Motyw listu odnajdujemy również w malarstwie XVIII wieku, przede wszystkim francuskim, choć można także wskazać przykłady angielskie i włoskie ${ }^{17}$. Poza typowymi przedstawieniami mężczyzn w sytuacjach oficjalnych i zawodowych, piszących, czytających czy też po prostu trzymających listy oraz poza portretami z listem jako atrybutem wykształcenia albo znakiem sprawowanej funkcji, spotykamy obrazy przedstawiające kobiety z listem, przy których czasem pojawia się służący lub kochanek. Najczęściej ukazane sa one we wnętrzu domowym, w prywatnym pomieszczeniu siedzące przy stoliku, przy kominku, na sofie, podczas toalety bądź oddające się miłym rozrywkom albo wreszcie umieszczone na łonie natury, wśród zieleni parku lub lasu, na ławce czy też przy drzewie. Listy są czytane albo tylko trzymane w dłoni, można zna-

16 Wiąże się to z tym, że aktywność kobiet ograniczana była do powinności pani do$\mathrm{mu}$, takich jak rozporządzanie wydatkami, nadzór nad służbą lub zlecanie zadań wiążących się z funkcjonowaniem gospodarstwa domowego. Kobiety nie były czynne zawodowo, nie prowadziły interesów i nie piastowały funkcji publicznych. Jednak oczywiście brały udział w życiu towarzyskim, nie tylko przez zabawy i rozrywki, lecz także przez związki z „kółkami dyskusyjnymi”.

$17 \mathrm{~W}$ wypadku malarstwa francuskiego list znajdujemy zwłaszcza u artystów rokokowych, wśród których można wymienić François Bouchera, Jeana-Honoré Fragonarda, Jeana-Baptiste'a-Siméona Chardina, Jeana-Baptiste'a Greuze'a, Jeana-Etienne'a Lyotarda, Jeana Roux. Możemy wskazać także kilku artystów angielskich, na których obrazach, choć nielicznych, znajdujemy też ten motyw - Thomasa Gainsborougha, Williama Hogartha, Joshuę Reynoldsa i wreszcie Włocha - Pietra Longhiego. W ten sposób motyw listu w XVIII wieku znajdowalibyśmy zasadniczo w trzech ośrodkach - Paryżu, Londynie i Wenecji. Zob. m.in. The Age of Watteau, Chardin, and Fragonard. Masterpieces of French Genre Painting, kat. wyst., red. C.B. Bailey, P. Conisbee, T.W. Gaehtgens, New HavenLondon 2003; J. Leymarie, Der Brief als Thema der Malerei, Genf 1967. 
leźć pojedyncze przykłady ich pisania, lakowania bądź odbierania. Często widzimy listy po prostu leżące na kominku, szafce, stoliku lub na podłodze, jakby zapomniane, będące jednym z licznych przedmiotów w pomieszczeniu. Wiele spośród tych dzieł jest niezwykle zmysłowych, niemal frywolnych, na co składa się przede wszystkim kokieteryjne, często niezbyt skromne zachowanie pokazanych kobiet.

Malarstwo XVIII wieku nie dostarcza tak licznego i bogatego przeglądu możliwych czynności związanych z listem oraz sytuacji, w których on się pojawia, jak holenderskie poprzedniego stulecia - nie tworzy się obrazów ukazujących całą procedurę pisania, wysyłania, dostarczania i odbierania listu, nie pojawiają się też właściwie posłańcy dostarczający lub odbierający korespondencję. List występuje w scenach rodzajowych często jako jeden $\mathrm{z}$ wielu przedmiotów $\mathrm{w}$ otoczeniu postaci, niemal jak zapodziany drobiazg rokokowy. W obrazach XVIII-wiecznych nie znajdujemy też rozbudowanej narracyjności holenderskich dzieł, nie skrywają treści alegorycznych i dydaktycznych, nie mają rozbudowanej i utrwalonej ikonografii gestów, czynności, postaci lub przedmiotów dopełniających sens przedstawienia. Jednak malarstwo to nie jest pozbawione narracyjności, obrazy opowiadają coś o postaciach i sytuacjach, w których te się znajdują. Dlatego stosunkowo łatwo rozpoznać w znacznej części przypadków np. temat miłosny dzięki ukazaniu pięknych i młodych kobiet w prywatnych pomieszczeniach i intymnych sytuacjach, wśród damskich fatałaszków i miłych drobiazgów, a ponadto pełne są delikatności, czułości i zmysłowości. Treści miłosnych można też doszukiwać się np. w przedstawieniach kobiety czytającej miłosny list kochanka stojącego obok, kobiety wycinającej serce na korze drzewa, obok którego leży list, czy też kobiety uśmiechającej się do widza tajemniczo i zalotnie, trzymającej zarazem przy twarzy bukiet kwiatów, spośród których wystaje liścik miłosny.

\section{Znaczenie listu w malarstwie}

Pojawienie się listu w malarstwie związane było nie tylko z sytuacją społeczną i kulturową, lecz także z jego atrakcyjnością dla sztuki holenderskiej lubującej się $\mathrm{w}$ tematach rodzajowych, przedstawieniach codziennego życia i ukazywaniu uczuć, dla sztuki, która uwielbiała realizm i iluzję oraz którą charakteryzowała predylekcja do mówienia na dwóch poziomach - literalnym i przenośnym, a więc do uzupełniania przekazu przez dodatkowe informacje. Służył temu wypracowany bogaty system ikonografii, co zwiększało i tak już spotęgowaną narracyjność tego malarstwa. Tę charakterystykę można też odnieść, choć w mniejszym stop- 
niu, do malarstwa XVIII wieku. Motyw listu dostarczył możliwości przedstawiania postaci $\mathrm{w}$ rozmaitych sytuacjach, pokazania ich zajęć, otoczenia, „opowiadania” historii o ich życiu i uczuciach, nasycenia dzieła dodatkowymi treściami zmysłowymi, a szczególnie miłosnymi18. Obraz fascynował i dawał radość jako dzieło pokazujące w realistyczny sposób świat codzienny, prywatny, a nawet intymny autentycznego człowieka, co stawiało widza w pewnym stopniu może niewygodnej, ale dostarczającej przyjemności sytuacji niby-podglądacza, zaspokajało jego ciekawość, dostarczało nawet pewnej wiedzy, a także pobudzało wyobraźnię, która interpretowała scenę i jednocześnie ją dopowiadała. Malarstwo to wabiło talentem i kunsztem malarskim, dzięki którym formalna strona dzieła była atrakcyjna i interesująca dla odbiorcy, oglądanie obrazu sprawiało mu przyjemność zmysłową, tak jak analizowanie oraz interpretowanie go budziło swego rodzaju rozkosze intelektualne. Obraz był atrakcyjnym wizualnie dziełem, kuszącym nie tylko kolorem, światłem, kompozycją, lecz także złudzeniami, iluzjonistycznymi zabiegami (ten aspekt jest słabiej obecny w wypadku malarstwa XVIII-wiecznego). Dzieło stanowiło zatem przestrzeń gry, a nawet zabawy $\mathrm{z}$ widzem zarówno ze względu na aspekty formalne i techniczne, jak i z powodu tematu, który mógł być rozwijany i dointerpretowywany poprzez odwoływanie się do ikonografii, emblematyki oraz zjawisk związanych $\mathrm{z}$ ówczesną kulturą i realiami społecznymi.

Chociaż list jest formą pisemnego przekazu pewnych treści, to w wypadku listu pojawiającego się w malarstwie prawdziwy i dający się odczytać, tekst rzadko kiedy zostaje przedstawiony. Poza tym list wraz ze swoją zawartością zazwyczaj nie jest zwrócony w stronę widza, więc w konsekwencji jego treść pozostaje prawie zawsze niedostępna dla odbiorcy znajdującego się poza obrazem. Ciekawymi przykładami odstępstwa od tej reguły mogą być dwa obrazy Jana Steena oraz dzieło Jeana-Honoré Fragonarda, w których widzimy namalowane listy z możliwymi

18 Umberto Eco, pisząc o pięknie w XVII wieku, posługuje się określeniami praktyczne i zmystowe. Ten pierwszy rodzaj piękna miałby być charakterystyczny dla obrazów holenderskich, a widoczny zwłaszcza w przedstawieniach kobiet, „w których piękno łączy się z praktycznym i pożytecznym" (U. Eco, Historia piękna, przeł. A. Kuciak, Poznań 2005, s. 208), co można tłumaczyć surowością wypływającą z kalwinizmu i obyczajów mieszczańskich. Nie można jednak powiedzieć, że sztuka ta pozbawiona jest zmysłowości, wręcz przeciwnie - kiedy uważniej przyjrzeć się obrazom, zwłaszcza rodzajowym przedstawiającym kobiety, nie sposób nie dostrzec piękna zmysłowego, a czasem nawet frywolności, tak jak nie sposób nie zauważyć uczuciowości, jaką są przepełnione, mimo że nie mogą jej wyrazić werbalnie. Jednak rzeczywiście piękno zmysłowe jest najczęściej spotykane w XVIII-wiecznej sztuce francuskiej, dominuje zwłaszcza w przedstawieniach kobiet w sytuacjach prywatnych i intymnych, a jego obecność wiąże się w dużym stopniu z ówczesną kulturą (którą określa m.in. rokoko) oraz sytuacją społeczną. 
do odczytania słowami ${ }^{19}$. Taki tekst, umieszczony przez malarza na namalowanym liście, odnosi się do przedstawionej sceny, jednoznacznie ją komentuje i objaśnia ${ }^{20}$. Zazwyczaj jednak list na obrazie pozostaje namalowaną kartką papieru z linijkami tekstu, jest więc listem umownie. Należy do elementów obrazu, które razem przedstawiają jakąś scenę, odnosząc się do rzeczywistości pozaobrazowej, choć pełni też funkcję znaku wskazującego na zdarzenia oraz uczucia i myśli postaci. Jednak nie wiadomo, czy jest on listem prywatnym, czy też oficjalnym lub zawodowym. A jeśli jest listem prywatnym, to i tak niełatwo stwierdzić, kto był nadawcą - czy członek rodziny, czy ktoś spośród przyjaciół, czy może wreszcie zalotnik lub ukochany. Dlatego należy zwrócić uwagę na pokazane na obrazach postacie, ich mimikę i gesty oraz otoczenie ze wszystkimi jego szczegółami, dzięki temu można bowiem odsłonić tajemnicę treści obrazu i to nie tylko na poziomie dosłowności przedstawienia, lecz także rozszerzoną do płaszczyzny znaczeń alegorycznych. List występujący w obrazie możemy zatem rozumieć po prostu jako list, zwykły przedmiot przedstawiony $\mathrm{w}$ zwyczajnej scenie rodzajowej albo jako przedmiot „znaczący”, co wydaje się słuszniejszą drogą interpretacji, a ponadto bardziej kuszącą.

\section{Powieść w listach}

Choć początki powieści epistolarnej wiążą się z XVII albo nawet z XVI stuleciem (wskazuje się np. na hiszpańską Processo de cartas Juana de Segury z 1548 roku), to triumfy święci ona w XVIII wieku. W XVII wieku wielką popularnością cieszyły się Listy portugalskie (1669) Gabriela Josepha de Lavergne, Comte de Guilleragues ${ }^{21}$, Lettres

${ }^{19}$ Batszeba z listem króla Dawida Steena (kolekcja prywatna) - w liście umieszczone zostały słowa: alder Schonte Bersabe - omdat, tzn. najpiękniejsza Betsabe - ponieważ; Wizyta doktora Steena (Alte Pinakothek, Monachium) - na namalowanym liście czytamy: „Daer baet geen medesijn, want het is minnepijn”, tzn. nie trzeba tu doktora, ponieważ to jest choroba miłosna; List miłosny Fragonarda - na namalowanej kartce papieru widnieją słowa: A Monsieur Cavalier lub jak uważają inni: Monsieur Mon Cavalier.

20 Obecność w sztuce listów, których słowa można odczytać powoduje też, że obraz jest nie tylko dziełem przedstawiającym jakiś fragment świata realnego lub fikcyjnego, ale zawiera w sobie elementy innego porządku znakowego - elementy rzeczywistości językowej. Za pomocą wzroku poznany zostaje obraz, jako dzieło przedstawiające oraz mówiące (w sensie dosłownym), wzrok jest zatem angażowany ze wzmożoną siłą, bowiem do oglądania ukazanej sceny oraz odczytania słów. W takiej sytuacji jednocześnie obraz przemawia $\mathrm{z}$ większą mocą, ponieważ potrafi przekazać więcej, posługując się słowem, które wyjaśnia lub dopowiada to, co ukazuje namalowana scena.

${ }^{21}$ Do XX wieku uważane za zbiór autentycznych listów portugalskiej zakonnicy Marianny Alcoforado do jej francuskiego kochanka. 
à Babet (1669) Edme'a Boursault oraz Listy miłosne między szlachcicem $i$ jego siostra (trzy tomy: 1684, 1685, 1687) Aphry Behn. W XVIII wieku nastąpiła eksplozja powieści w listach i jednocześnie był to okres największej świetności tego gatunku: w Anglii ukazała się Pamela (1740) i Klarysa (1748) Samuela Richardsona, we Francji Nowa Heloiza (1761) Jeana Jacques'a Rousseau oraz Niebezpieczne zwiazki (1782) Pierre'a Choderlosa de Laclos, a w Niemczech Cierpienia mtodego Wertera (1774) Johanna Wolfganga Goethego. W całej, tworzącej wspólnotę kulturową, Europie Zachodniej powieści epistolarne wyrastały z jednakowej tradycji, miały wspólny kontekst, były więc do siebie podobne pod wieloma względami. Poza Anglią, Francją i Niemcami powieść epistolarna rozwijała się także we Włoszech i Hiszpanii, a także w Europie Środkowej i Wschodniej, czego przykładem są polskie lub rosyjskie powieści w listach albo powieści, w których listy odgrywają znaczącą rolę22.

Gatunek był więc popularny i znany w całej Europie, jednak utwory napisane w Polsce lub w Rosji różnią się od tych z Zachodu, ponieważ posługują się formą przejętą, której same nie wykształciły i która w związku z tym zaczęła funkcjonować w odmiennych warunkach społecznych i kulturowych, więc mogła służyć odmiennym celom i inaczej być odbierana. Jak już zostało powiedziane, po XVIII wieku powieść epistolarna straciła swoją siłę oraz popularność i choć czasem posługiwali się nią pisarze, nie miała takiego znaczenia dla konkretnych dzieł i całej literatury, jak w XVIII stuleciu ${ }^{23}$.

Krystalizacja gatunku powieści w listach związana była ze wskazanymi zmianami społecznymi i kulturowymi, ale szczególne znaczenie miał także sam list i jego właściwości, atrakcyjne dla powieści. Za wpływające na narodziny powieści epistolarnej uważa się często formy mające ją poprzedzać, tzn. powieści, do których włączane były listy (z czasem miało być ich coraz więcej, a mniej rozdzielającej je trzecioosobowej narracji) lub zbiory różnorodnych listów zarówno prawdziwych, jak i fikcyjnych (np. podręczniki pisania listów gromadzące różne przykłady epistolograficzne) - niektóre listy miały łączyć się ze sobą tematycznie

22 Spośród polskich powieści epistolarnych można wymienić m.in. Malwine czyli Domyślność serca (1816) Marii Wirtemberskiej i utwór Juliana Ursyna Niemcewicza Lejbe i Siora czyli Listy dwojga kochanków (1822), które choć napisane na początku XIX wieku pod względem swojej charakterystyki należą do zjawisk właściwych dla XVIII-wiecznej Europy Zachodniej. Analizę rosyjskich powieści w listach podejmuje Maarten Franje w swojej książce The Epistolary Novel in Eighteenth-Century Russia, Leiden 2000 (zob. zwłaszcza s. 13-37 oraz 137-148).

${ }^{23}$ P.C. Sutton, Love Letters..., dz. cyt., s. 14. Zob. hasła powieść oraz powieść w listach Michała Głowińskiego w: Stownik terminów literackich, red. M. Głowiński, T. Kostkiewiczowa, A. Okopień-Sławińska, J. Sławiński, Wrocław 2002, s. 416-419 oraz 424-425. 
i w ten sposób zyskiwać samodzielność oraz status tekstu literackiego ${ }^{24}$. I tak np. Pamela, uchodząca za pierwszą powieść epistolarną, powstała z napisanych przez Richardsona listów, których zbiór pełnić miał funkcję podręcznika pisania i działania - miał to być zbiór listów prywatnych pisanych „potocznym stylem na tematy, które mogłyby okazać się użyteczne dla tych wiejskich czytelników, co sami listów układać nie potrafią"25. Listy miały dostarczać nie tylko wzorów stylistycznych i tematycznych korespondencji, lecz także dawać wskazówki moralne służące właściwemu myśleniu i działaniu, o czym zresztą informuje pierwotny tytuł zbioru ${ }^{26}$. Jednak nie tylko listy, prawdziwe lub fikcyjne, zainspirowały powieść i zostały przez nią wykorzystane, lecz także powieść epistolarna wpłynęła na epistolografię, „na sposoby listowania uprawiane przez rzeczywistych korespondentów w zupełnie niefikcyjnym świecie"27. To współistnienie i wzajemne przenikanie się zjawisk obserwować można od samego początku - kiedy dzieła Richardsona i Nowa Heloiza ustaliły wzorzec gatunku, odwoływały się do nich kolejne powieści w listach oraz czerpała z nich inspirację autentyczna korespondencja.

Wyraża się też przekonanie, że gatunek powieści w listach wyrósł z opozycji do obowiązujących, a skostniałych i mało już atrakcyjnych form, reguł oraz schematów, m.in. jako wyraz krytycznego stanowiska względem dotąd znanej literatury, że stanowił „przejście od obiektywnej, społecznej i publicznej orientacji świata klasycznego do subiektywnych, indywidualistycznych i prywatnych orientacji w życiu i literaturze"28.

24 Przekonanie takie wyraża np. Svetlana Alpers, która twierdzi, że to listy z podręczników pisania listów dostarczyły wzorów formalnych i ram narracyjności pierwszym powieściom epistolarnym, a sama moda na te podręczniki zainspirowała powstanie takiej literatury. S. Alpers, The Art of Describing..., dz. cyt., s. 196.

${ }^{25}$ I. Watt, Powieść a doświadczenie osobiste, [w:] tegoż, Narodziny powieści. Studia o Defoe'em, Richardsonie i Fieldingu, przeł. A. Kreczmar, Warszawa 1973, s. 224.

${ }^{26}$ „Letters Written To and For Particular Friends, on the most Important Occasions. Directing not only the Requisite Stile and Forms To be Observed in Writing Familiar Letters; But How to Think and Act Justly and Prudently, in the Common Concerns of Human Life". T.O. Beebee, Epistolary Fiction in Europe 1500-1850, dz. cyt., s. 35. O publikowanych zbiorach listów, które stawały się rodzajem podręcznika nie tylko pisania listów, ale postępowania, oddziaływania i wpływania na odbiorcę, pisze Beebee w rozdziale Ars dictaminis: the letter writer in the machine (tamże, s. 18-47). Mówi o tym także Sutton: „The letter manuals of the period offer much more than stock solutions to writer's block; they provide a manual of conduct and civility, enabling an individual to address what were then regarded as virtually all life's challenges and relationships, with tact, courtesy, and pliant affability - in short, a blueprint for "politesse " and admission to courtly society". P.C. Sutton, Love Letters..., dz. cyt., s. 33.

27 M. Czermińska, Pomiędzy listem a powieścia, dz. cyt., s. 32.

${ }^{28}$ I. Watt, Powieść a doświadczenie osobiste, dz. cyt., s. 208. Badacz pisze też o znaczeniu listu dla powieści epistolarnej: „forma listu otworzyła Richardsonowi prostą drogę do serc i pozwoliła mu wyrażać to, co w nich znalazł, z możliwie największą precyzją, 
W końcu XVII wieku autorzy chcieli wyzwolić twórczość literacką ze sztuczności retoryki, galanterii, teatralności, ważności reguł i formy, a czytelnicy zainteresowani byli nowymi tematami i formami literackimi. Celem pisarzy przestało być tylko zaciekawienie przygodami lub pouczenie przykładem, pragnęli bowiem teraz przybliżać fikcję literacką do życia. Dążono do szczerości i bezpośredniości, prawdy i naturalności, które przejawiały się $\mathrm{w}$ tematyce ukazującej codzienność oraz świat prawdziwych pasji i uczuć, w języku, a nawet w nowej formie, czego rezultatem miało być dzieło oryginalne i naśladujące empiryczną rzeczywistość, takie właśnie jak powstające powieści epistolarne ${ }^{29}$.

Istotna dla osiągnięcia tego celu była tu zarówno treść, jak i forma, która wprowadzała coś nowego do literatury, atrakcyjnego zarówno dla twórców, jak i czytelników, a zarazem znanego z codziennej rzeczywistości. List okazał się tak popularny i pożądany, że pisarze postanowili posłużyć się nim w swoich utworach, a czytelnicy chcieli z nim obcować nie tylko poprzez swoją korespondencję, lecz także w tekstach literackich. Równie istotne jak same listy, tworzące materię powieści, są tytuł i przedmowa, które „stanowią część utworu, współtworzą jego poetykę i wskazują na nią", są swego rodzaju manifestami literackimi, metawypowiedziami w powieści ${ }^{30}$. Nie tylko dają wykład poetyki, lecz także są pole-

choćby za cenę ryzyka, że zaszokuje zwolenników tradycji w literaturze”. Tamże, s. 231232. Można obserwować w tym czasie przemiany samych listów - karierę robił list pisany tak, jakby prowadziło się sprawną konwersację lub dowcipną pogawędkę z drugą osobą, list pozbawiony sztuczności i oschłości, zbędnych konceptów i nadmiernej elegancji, wykorzystujący monolog, pozorny dialog, wyznanie, medytację, także opis i opowiadanie, przytoczenia oraz sentencje. Zob. A. Aleksandrowicz, Preromantyczne listowanie..., dz. cyt., s. $72-73$.

${ }^{29}$ Pisze też o tym Małgorzata Czermińska, kiedy analizuje zjawisko kontaktowania się z literaturą tekstów stojących na pograniczu form literackich i użytkowych lub dokumentalnych (list, pamiętnik, dziennik, autobiografia). Badaczka pisze bowiem o dwóch procesach: narodziny, rozwój i przemiany powieści nowoczesnej, z którymi wiązała się „subiektywizacja i liryzacja powieści, eseizacja, nasycenie jej refleksją autotematyczną (...) polimorficzność, polegająca na włączeniu w tekst powieści rozmaitych, konwencjonalnie uznanych za niepowieściowe, form wypowiedzi” oraz zmiany postawy i zainteresowań czytelników - „proces stałego wzrostu zainteresowania czytelniczego właśnie prozą pozapowieściowa, pozafabularną: biografistyka, eseistyką, reportażem”, a w szczególności pismami intymnymi. M. Czermińska, Rola odbiorcy $w$ dzienniku intymnym, [w:] Problemy odbioru i odbiorcy, studia pod red. T. Bujnickiego, J. Sławińskiego, Wrocław 1977, s. 105-106.

30 D. Danek, Zwiazek między tytutem utworu literackiego i poetyka utworu (na przykładzie powieści epistolarnej XVIII w.), [w:] taż, Dzieło literackie jako ksiażka. O tytułach $i$ spisach rzeczy w powieści, Warszawa 1980, s. 32. Zob. też: D. Danek, Tytut i przedmowa - $i$ spór o fakt literacki (filologia antropologiczna contra pozytywizm), [w:] taż, Dzieło literackie..., dz. cyt. Problem metadyskursu obecnego w powieści epistolarnej omawia Andrzej Rabsztyn, pisze m.in. o znaczeniu przedmowy jako metawypowiedzi - La préface w: 
miczne w stosunku do zastanych reguł literackich i wzorów gatunkowych $^{31}$. Przede wszystkim są jednak konwencjonalnym zabiegiem wykorzystywanym $\mathrm{w}$ powieściach epistolarnych. Chodzi bowiem o to, że „przez cały wiek XVIII rozwija się w powieści inscenizacja, której celem jest stworzenie wrażenia prawdziwości tekstu literackiego"32. Stąd pojawiające się w tytułach i przedmowach powieści epistolarnych informacje o znalezieniu lub otrzymaniu rękopisu bądź listów, zatem tekstów o charakterze prywatnym, czasem nawet intymnym, które miałyby być prawdziwe, a które rzekomy wydawca tylko redaguje i wydaje po to, aby udostępnić je publiczności. Jak pokazują przykłady znanych powieści epistolarnych, wydawca ów miał tylko nadać tytuł, opatrzyć zbiór przedmową i odpowiednimi przypisami czy też komentarzami wyjaśniającymi jego działania, ewentualnie jeszcze dodać część końcową, w której dopowiadane były losy bohaterów (jak ma to miejsce np. w Cierpieniach młodego Wertera). Nie należy takiego postępowania interpretować jako kłamstwa albo sztuczki autora, ale trzeba w nim widzieć wysublimowaną grę twórcy z czytelnikiem i budowanie odpowiedniego kontekstu dla powieści. Był to bowiem zabieg bardzo popularny w literaturze XVIII wieku, a wywołane wrażenie prawdziwości i dostępu do prywatności powodowało, że czytelnicy z wielką przyjemnością rozczytywali się w takich dziełach. W rezultacie popularne powieści w listach miały wówczas po

A. Rabsztyn, L'écriture et le langage dans le roman épistolaire français et polonais de 1760 à 1820, Katowice 2005, zwłaszcza s. 94-108 oraz 127-133.

${ }^{31}$ D. Danek, Związek między tytułem utworu literackiego i poetyka utworu, dz. cyt., s. 24, 25. W przedmowie do drugiego tomu Pameli domniemany wydawca wyraża nadzieję, że zawarte w nim listy „w tej samej mierze uznane zostaną za napisane zgodnie z naturą, że stwierdzi się w nich taki sam brak wszelkich powieściowych ucieczek, nieprawdopodobnych niespodzianek i wszelkiej irracjonalnej maszynerii”. Tamże, s. 14 oraz 24-25. Podobna w wymowie jest druga przedmowa do Nowej Heloizy, wydana osobno w marcu 1761 roku, dłuższa w porównaniu z pierwszą i napisana w formie dialogu (Przedmowa do Nowej Heloizy: czyli rozmowa o powieściach. Między wydawca a pewnym literatem. Przez J.-J. Rousseau, obywatela Genewy), w której Rousseau spotyka się z zarzutami rzekomego swego rozmówcy i mówi: „Zresztą pan krytykuje utwór, który przeczytał pan jako powieść (...) Przecież to zbiór listów...”. Podkreśla więc, że utwór, o którym rozmawiają, to nie fikcja literacka, powieść taka, jaką ją znali ówcześni, ale zbiór listów, coś „z życia wzięte”, coś nowego i innego. I dalej: „Widzę, że wolałby pan listy pisane od razu do druku (...) A więc będziemy mieli w książkach ludzi takimi jedynie, jakimi pragną się nam wydawać?" Pisarz podkreśla zatem znaczenie naturalności, zjawisk przypominających życie, a nie literaturę z jej uładzeniem i wyszukaniem. Domaga się prawdy, którą mogą pokazać właśnie prawdziwe listy rzeczywistych ludzi lub dzieło literackie, które imitowałoby taką prawdziwość i naturalność w sposób doskonały. J.J. Rousseau, Nowa Heloiza, przeł. i oprac. E. Rzadkowska, Wrocław 1962, s. 417-418.

32 J.M. Goulemot, Praktyki literackie albo jawność życia prywatnego, [w:] Historia życia prywatnego, dz. cyt., s. 450. 
kilkadziesiąt wydań i przeróbek, czytano je z pasją, niemal gorączkowo, a nowe egzemplarze rozchodziły się błyskawicznie i pożyczano je sobie nie na dni, ale na godziny. Powieść ta chciała łudzić czytelników, że maja do czynienia z rzeczywistymi listami, z prawdziwymi ludźmi i ich prywatną korespondencją, która pozwala poznać ich codzienne życie, świat uczuć i myśli, ich najskrytsze tajemnice ${ }^{33}$. Poprzez wykorzystanie listu oraz specyfikę tytułu, przedmowy i przypisów chciała zatem stworzyć iluzję autentyczności publikowanego tekstu. Czytelnicy podejmowali tę grę, nie dawali się jednak zazwyczaj zmylić, że mają do czynienia $\mathrm{z}$ fragmentami rzeczywistości, z autentyczną korespondencją, ale mimo to łudziła ich i zachwycała wspaniale naśladowana naturalność i prawda języka, stylu oraz treści.

Powieść w listach budują powiązane tematycznie listy jednej lub kil$\mathrm{ku}$ postaci relacjonujące zdarzenia minione i budujące aktualne. Korespondencja ta dotyczy prawie wyłącznie spraw prywatnych - rodzinnych, przyjacielskich, a przede wszystkim miłosnych. Tworzy całość o wyraźnej, choć czasem dość ograniczonej fabule, ponieważ najistotniejsze okazują się analiza osobowości, refleksje i emocje postaci. Pokazane zostaje ich domowe, prywatne, a nawet intymne życie, wewnętrzny świat ich emocji i myśli. Poznajemy działania bohaterów, ich zwyczajne, codzienne czynności, m.in. zapełniające wolny czas rozrywki - śpiewanie lub granie na instrumentach, rysowanie, wykonywanie ręcznych robótek, gry w szachy i karty, wizyty w operze i teatrze, spotkania towarzyskie na kolacjach i balach, wspólne konwersacje, spacery oraz przechadzki, wreszcie czytanie książek i prowadzenie korespondencji. Duże znaczenie ma również materialne otoczenie postaci oraz przyroda, w której odnajdują one odbicie swego wnętrza i która kształtuje ich nastroje. Kluczową rolę odgrywają uczucia bohaterów, wyrażane przez nich opinie na różne tematy, ich plany i oczekiwania. Głównie też o tym piszą w swojej korespondencji lub czytają w listach od przyjaciół, członków rodziny oraz ukochanych ${ }^{34}$. Czytelnik śledzi więc bieg wydarzeń, poznając pisemne

${ }^{33}$ Zob. M. Franje, The Epistolary Novel..., dz. cyt., s. 145. To zagadnienie omówione jest też w pracy Annette Anton - Authentizität als Fiktion. Briefkultur im 18. und 19. Jahrhundert, Stuttgart-Weimar 1995, w której autorka przygląda się listom jako rodzajowi gry, kłamstwa i łudzenia; analizuje prawdziwą korespondencję, ponadto listy z podręczników pisania listów oraz listy w powieści, ich umiejscowienie na granicy autentyczności i fikcjonalności.

34 Jak piszą badaczki w analizach powieści epistolarnych: „Nowa Heloiza to pierwsza powieść roztrząsająca wszelkie doświadczenie wewnętrzne człowieka, nie poprzestając na analizie miłości, jednak zauważono przede wszystkim jej sentymentalną stronę i społeczeństwo (...) oddało się całe rozkoszy łez, westchnień i zachwytów (...) Prawa serca 
konwersacje kobiece i męskie, przez co nie tylko ma wgląd w prywatne i wewnętrzne życie postaci, lecz także widzi prawdziwe przyczyny i cele działań bohaterów, ich wątpliwości, rozterki, złudzenia czy też snute intrygi, może porównać ich rzeczywiste uczucia i myśli z tym, co okazują na zewnątrz. Zapoznaje się również ze zróżnicowaną, nie tylko tematycznie, lecz także stylistycznie, korespondencją różnych postaci - obok listów bardzo lirycznych, pełnych emfazy i afektacji, są takie, które przypominają sprawozdanie lub dygresyjny esej, a także moralizatorskie.

W powieści epistolarnej listy są właściwie jej jedynym budulcem, w wyniku czego występuje wyłącznie mowa niezależna, pierwszoosobowe i z istoty pisemne wypowiedzi postaci oraz porzucony zostaje narrator (szczątkowej jego obecności można się dopatrywać w wypowiedziach rzekomego wydawcy w przedmowie, przypisach lub epilogu). Nie występuje tu właściwie dystans między piszącymi a czytelnikiem, który ma bezpośredni dostęp do listów, podobnie między czasem akcji a czasem narracji, ponieważ działania korespondujących ze sobą postaci budują akcję i na bieżąco zdają one $\mathrm{z}$ nich relację $\mathrm{w}$ listach. Bliskość czasowa wydarzeń oraz zaangażowanie $\mathrm{w}$ nie postaci tłumaczy emocjonalny, czasem nawet emfatyczny styl oraz swoisty dramatyzm - dowiadujemy się o działaniach, przeżyciach, emocjach i opiniach danej postaci wprost od niej samej i niemal w momencie, w którym one się dzieją lub tuż po ich zaistnieniu, więc stajemy się ich bezpośrednimi świadkami. Ponadto mamy dostęp nie tylko do poszczególnych listów, ale możemy obserwować dynamiczna wymianę całej korespondencji między wszystkimi postaciami. Akcja stwarza się zatem niejako na naszych oczach, a listy nie tylko zdają relację z wydarzeń, lecz także w nich uczestniczą, mogą powodować jakieś działania postaci i zmieniać bieg dziejącej się historii, zatem

(...) stały się podstawą nowych sądów i ocen, którym nie wystarczył autorytet rozumu". E. Rzadkowska, Nowość i oryginalność dzieła, [w:] J.J. Rousseau, Nowa Heloiza, s. XI i E. Rzadkowska, Publikacja „Nowej Heloizy” i jej znaczenie dla wspótczesnych, [w:] J.J. Rousseau, Nowa Heloiza, dz. cyt., s. LIII. Zob. też: J. Starobinski, Nowa Heloiza, [w:] tegoż, Jean-Jacques Rousseau. Przejrzystość i przeszkoda, przeł. J. Wojcieszak, Warszawa 2000, s. 101-147. O uczuciach w Nowej Heloizie pisze też Arne Melberg: „wszystkie uczestniczące w niej [powieści] osoby ogarnięte są obsesją miłości, ponieważ dzieli je pewien dystans, równie obsesyjnie piszą do siebie listy, które odmierzają dystans czasowy i przestrzenny, a zarazem dobitnie wyrażają potrzebę bliskości, tożsamości i równoczesności, a więc także potrzebę miłości”. A. Melberg, Rêverie Rousseau, [w:] tegoż, Teorie mimesis. Repetycja, przeł. J. Balbierz, Kraków 2002, s. 109. O. Dobijanka-Witczakowa pisze o autorze Cierpień młodego Wertera: „stawiał w centrum problem wielkiej namiętności, wnikał głęboko w psychikę jednostki, akceptował niejako jej subiektywny punkt widzenia”. O. Dobijanka-Witczakowa, Forma powieści i fabuła, [w:] J.W. Goethe, Cierpienia młodego Wertera, przeł. L. Staff, oprac. O. Dobijanka-Witczakowa, Wrocław 2000, s. XXXIX. 
są zdolne współtworzyć fabułę i rozwijać akcję ${ }^{35}$. Właściwie każdy list ze względu na swoją szczerość i naturalność, lub ich brak, ma wielkie znaczenie zarówno dla charakterystyki postaci, jak i dla rozwoju wydarzeń. Wpływ na dramatyzm powieściowej korespondencji ma też podejmowany temat - im bardziej dotyczy świata prywatnego i intymnego, zwłaszcza uczuciowego, tym większy wprowadza dynamizm ${ }^{36}$. Poza tym istotna jest również liczba osób, których listy budują powieść oraz obecność odpowiedzi na te listy. I tak w zależności od tego, czy mamy do czynienia z pozbawionymi odpowiedzi listami jednej tylko osoby czy z wymianą korespondencji między dwiema osobami lub większą liczbą postaci, możemy mówić o formach monologowych lub dialogowych w powieści (albo jeszcze polilogowych, jak chce Franje) bądź jedne przyrównywać do dzienników lub pamiętników, a drugie nazywać dramatycznymi wypowiedziami ${ }^{37}$.

$\mathrm{W}$ wyniku wykorzystania listu $\mathrm{w}$ powieści $\mathrm{w}$ listach pojawiają się jednak również pewne trudności, np. „konieczność pogodzenia żywiołu epickiego, którego jedną z form jest powieść, z żywiołem refleksyjno-lirycznym listu, wobec którego element epicki odgrywa rolę trzeciorzędną"38 - trzeba wtłoczyć w niego epickość, ale tak, aby go nie zdominowała, ponieważ utraciłby wówczas swoją prawdziwość. Pisarze muszą zatem umiejętnie przemycać $\mathrm{w}$ listach informacje, które są niezbędne czytelnikowi do zrozumienia całej fabuły, ale jednocześnie nie obciążają nienaturalnie treści i stylu listu. Powieść wykorzystuje więc formę listu, ale nie traci swoich właściwości - musi je pogodzić z właściwościami li-

${ }^{35}$ List wpływa na rozwój akcji wówczas, gdy np. jego przeczytanie staje się zdarzeniem rozstrzygającym lub wyjaśniającym jakąś sytuację, bezpośrednio wpływającym na losy postaci. Dzięki listom „powieść stanowi raczej »dramatyczną narrację" niż »opowiadanie«”, jak pisał Watt o Klarysie Richardsona, a co można odnieść również do innych powieści epistolarnych. I. Watt, Richardson jako powieściopisarz - „Clarissa”, [w:] tegoż, Narodziny powieści, dz. cyt., s. 249. Podobne ogólne znaczenie ma uwaga Andrzeja Siemka: „list u Laclosa jest faktem w mocnym znaczeniu tego słowa - nie komentarzem, dołączonym do tego, co się dzieje, ale przedmiotem aktywnie obecnym wśród działających postaci i instrumentem tego działania”. A. Siemek, Posłowie, [w:] P.-A.-F. Choderlos de Laclos, Niebezpieczne zwiąki czyli Listy zebrane $w$ jednym społeczeństwie a ogłoszone ku nauce innych, z franc. przeł. T. Żeleński (Boy), przekład uzupełnił i posłowiem opatrzył A. Siemek, Warszawa 2001, s. 409. Zob. też: F. Meltzer, Laclos' Purloined Letters, „Critical Inquiry”, Vol. 8, No. 3 (Spring 1982).

${ }^{36}$ Regularna wymiana takich listów buduje „obraz wewnętrznego »dziania się«, dramatyzm uczuć i wydarzeń”. A. Aleksandrowicz, Preromantyczne listowanie..., dz. cyt., s. 68. Zob. rozważania Andrzeja Rabsztyna w rozdziale La representation de l'acte d'écriture, [w:] A. Rabsztyn, L'écriture et le langage, dz. cyt., s. 137-181.

${ }^{37}$ Zob. M. Franje, The Epistolary Novel..., dz. cyt., s. 20-22. O różnicy między dziennikiem a listem, soliloquium i colloquium zob. M. Czermińska, Rola odbiorcy $w$ dzienniku intymnym, dz. cyt., s. 111-116.

38 S. Skwarczyńska, Teoria listu, dz. cyt., s. 355. 
stu, ponieważ utworowi „narzucone są wymagania formy, w której obrębie naśladowania się dokonuje” 39 . Innym problemem ,jest takie ujęcie akcji, aby listy nie musiały być sprawozdaniami dokonanych momentów akcji, lecz, by płynęły równolegle, towarzyszyły stawaniu się"40. Jak widać, kłopoty związane są z nieprawdopodobieństwem sytuacji, z jaką mamy do czynienia w powieści epistolarnej, a mianowicie takiej, że ktoś ciągle pisze listy, w których daje wyraz nie tylko swojemu stanowi emocjonalnemu, swojej świadomości, ale też opowiada o wszystkich mających miejsce zdarzeniach, nawet błahostkach. Choć właściwie można takie zachowanie uzasadniać popularnością listu i praktyką, której nie było obce pisanie nawet kilku listów dziennie ani zabawy towarzyskie polegające na tym, że zamiast rozmawiać, pisano do siebie liściki. Innym problemem jest jeszcze sposób, w jaki nadawca listu relacjonuje zdarzenia - tak, jak ma to w zwyczaju pamiętnik i autobiografia (z oddalenia czasowego) albo tak, jak robi to dziennik (na bieżąco, w teraźniejszości). Wydaje się, że większą siłę perswazyjną mają zapiski czynione na bieżąco i zasadniczo właśnie $\mathrm{w}$ ten sposób piszą bohaterowie powieści w listach. Widać więc, że listy pozostają prawdziwymi bohaterami powieści, kształtują ją i są jej tematem.

\section{List $w$ powieści $w$ listach}

W wypadku powieści epistolarnej obserwujemy niejako pełne wykorzystanie formy listu przez literaturę, listy budują tu bowiem całą powieść, stanowią jej istotę ${ }^{41}$. Powieść ta chciała przedstawiać życie osobi-

${ }^{39}$ Zob. hasło mimetyzm formalny Michała Głowińskiego w: Słownik terminów literackich, dz. cyt., s. 311. Gdzie indziej Głowiński pisze: „powieść naśladująca wzorce np. pamiętnika lub dziennika dokonuje ich upowieściowienia, a więc siłą rzeczy ujawnia inne właściwości niż te, które dla wzorca owego były istotne na terenie macierzystym, mimetyzm formalny nie polega na pełnym upodobnieniu obu rodzajów wypowiedzi, uległości literatury wobec typów wypowiedzi, które wykorzystuje”. M. Głowiński, O powieści $w$ pierwszej osobie, [w:] tegoż, Gry powieściowe. Szkice z teorii $i$ historii form narracyjnych, Warszawa 1973, s. 64. Badacz mówi o różnicach między dziennikiem intymnym a powieścią, które można odnieść do stosunku listów i powieści w listach: powieść ma zawsze sens globalny, jest zorganizowaną według jakichś z góry przyjętych zasad całością - m.in. przez chronologiczne następstwo zdarzeń, ma początek i zakończenie, jest monotematyczna, musi zachować narracyjność, najczęściej występuje w niej narrator niejako nadrzędnie porządkujący całość tekstu - cechy te nie są właściwe listowi, ale większość z nich odnajdujemy w powieści zbudowanej z listów, zachowuje ona więc pewne właściwości powieści, zarazem jednak przyjmuje właściwości listów. Zob. M. Głowiński, Powieść a dziennik intymny, [w:] tegoż, Gry powieściowe, dz. cyt., s. 79-83.

40 S. Skwarczyńska, Teoria listu, dz. cyt., s. 357.

41 Zob. M. Czermińska, Pomiędzy listem a powieścia, dz. cyt., s. 28-29. 
ste oraz wewnętrzne postaci w sposób najbardziej prawdopodobny, tak, aby wszystko wydawało się prawdziwe. Posłużyła się listem ze względu na jego właściwości: bezpośredniość przekazu; możliwość kontaktu i poczucia bliskości mimo odległości; uobecnianie nieobecnej osoby; szczerość i emocjonalność w przekazywaniu wiadomości o toczącym się życiu, codziennej i prywatnej rzeczywistości, o uczuciach, myślach i wrażeniach; możliwość wprowadzenia rozważań na temat rozmaitych kwestii emocjonalnych, moralnych, społecznych i estetycznych; związanie z prawdziwym życiem, bycie jego cząstką, a zarazem odbiciem ${ }^{42}$. List doskonale nadawał się do pokazania codziennego życia prywatnego oraz duchowego konkretnej jednostki, zwłaszcza gdy był to list prywatny, a taki właśnie powieść przyswoiła. Miał naśladować zarówno formalnie, jak i treściowo ówczesne listy, miał być jak one dokumentarnym świadectwem rzeczywistości, portretem prawdziwego życia, lustrem odbijającym duszę - zadaniem listu było „możliwie pełne ukazanie wewnętrznych przeżyć bohatera, podanie najsubtelniejszych motywów jego postępowania"43. Miał on nie tylko dawać wgląd w czyjeś prywatne życie, lecz także przedstawiać je bezpośrednio w momencie jego dziania się, tak aby można było o liście powiedzieć, że „stwarza efekt rzeczywistości oraz wywołuje uczucie obecności i bycia w "teraz" "44. Posłużenie się listami występującymi w codziennej rzeczywistości wiązało się też $\mathrm{z}$ wprowadzeniem odpowiedniego stylu - m.in. z używaniem naturalnej, żywiołowej mowy oraz potocznych słów i zwrotów ${ }^{45}$. Wykorzystanie listu, połączenie romansu i realizmu

${ }^{42}$ Zob. rozdz. Introduction: letters, genealogy, power, [w:] T.O. Beebee, Epistolary Fiction in Europe 1500-1850, dz. cyt., s. 1-17.

${ }^{43}$ O. Dobijanka-Witczakowa, Forma powieści i fabuła, [w:] J.W. Goethe, Cierpienia młodego Wertera, dz. cyt., s. XXXII. Zagadnienie intymności w listach budujących powieść epistolarną, ukazywania przez nie duchowego, wewnętrznego życia postaci rozwinięte zostało przez Reginę Bochenek-Franczakowa w rozdziale La vie intérieure w jej książce: Le personnage dans le roman par lettres à voix multiples de „La Nouvelle Héloüse” aux „Liaisons dangereuses”, Kraków 1996, s. 129-183.

44 A. Melberg, Rêverie Rousseau, dz. cyt., s. 116.

$45 \mathrm{O}$ znaczeniu odpowiedniego stylu listu, nawet jeśli nie odpowiada on schematom i regułom stylu wysokiego, nie jest elegancki i błyskotliwy, pisał Rousseau w drugiej przedmowie do Nowej Heloizy: „list naprawdę podyktowany przez miłość, list namiętnego kochanka będzie niedbały, rozwlekły, pełen dłużyzn, nieporządku, powtórzeń (...) Jeśli siła uczucia nie zdoła nas zachwycić, wzruszy jego prawda (...) Nie znajdziemy w nich [listach] wdzięku i lekkości, nie spotkamy się z rozsadkiem, dowcipem, elokwencją: ale dostrzeżemy uczucie”. J.J. Rousseau, Nowa Heloiza, dz. cyt., s. 419-420, 424. Na temat właściwego i przekonującego stylu oraz emocjonalności korespondencji wypowiada się również markiza de Merteuil w Niebezpiecznych zwiazkach i stwierdza: „To wada wszystkich romansów; autor dobywa ostatniego tchu, aby się rozgrzać, a czytelnik pozostaje zimny. Jedna »Heloiza" stanowi może wyjątek, toteż, mimo całego talentu autora, nigdy nie mogłam oprzeć się wrażeniu, że tło tego romansu musi być prawdziwe”. P. Choderlos de Laclos, Niebez- 
formalnego, wciągającego tematu i lekkości formalnej, braku sztuczności i obcości dało w rezultacie powieści epistolarnej potężne oddziaływanie i niezwykłą popularność.

Aby wzmocnić ten efekt, autorzy podawali się tylko za wydawców przedstawianego zbioru listu i zrzekali chwały twórców. Wiarygodności oraz wartości listom dodawał sam autorytet druku, tzn. złudzenie, że to, co wydrukowane, jest prawdziwe, pozbawione błędu lub oszustwa. Obok znaczenia druku istotny był też podejmowany temat prywatności oraz intymności, a razem decydowały w pewnym stopniu o poczuciu prawdziwości tekstu - „to, co intymne sprawia wrażenie prawdziwości, lecz tylko wówczas, gdy trafia do wiadomości publicznej (...) Prywatność tylko wtedy jest prawdziwa, gdy staje się powszechnie znana"46. W ten sposób powieść stawała się bardziej atrakcyjna i interesująca - budziła zaciekawienie, a nawet podniecenie, ponieważ kusiła i łudziła autentyzmem nie tylko sposobu przedstawienia świata postaci, lecz także autentyzmem siebie jako nieliteratury, jako zbioru prawdziwej korespondencji. Dla odbiorców bardzo przyjemne, zaspokajające ciekawość, a zarazem pobudzające wyobraźnię, było oglądanie prywatnego świata zewnętrznego, a tym bardziej wewnętrznego postaci. Przyciągało ich cudze życie prywatne, stawali się jakby podglądaczami i to mającymi niezwykłe możliwości płynące z czytania czyjejś osobistej korespondencji. Mieli bowiem wgląd nie tylko $\mathrm{w}$ to, co objawia się na zewnątrz, lecz także w rzeczywistość ukrytą i niedostępną - we wnętrze duszy i serca ${ }^{47}$. Przypomina to zaglądanie przez dziurkę od klucza do czyjegoś pokoju lub zaglądanie przez specjalny otwór do kasety perspektywicznej. W wypadku powieści epistolarnej takim otworem, dzięki któremu czytelnik mógł zaglądać do wewnątrz, do świata prywatnego i duchowego, był właśnie list. Wytwarzała się przez to swoista emocjonalna więź między czytelnikami i korespondującymi postaciami. Wydawały się one bowiem tak realne, a ich uczucia i myśli tak przekonujące, że czytelnik często utoż-

pieczne związki, przeł. i wstępem opatrzył T. Boy-Żeleński, Kraków 2003, cz. I, list XXXIII, s. 63. Ta informacja o powieści epistolarnej może być traktowana jako metatekstowa wypowiedź pisarza ustami jednego ze swoich bohaterów na temat literatury, na temat gatunku, którym sam chce się mistrzowsko posługiwać. Może być też widziana jako pojawiająca się w rzeczywistym liście i dotycząca popularnej powieści epistolarnej opinia damy z wyższej sfery francuskiego społeczeństwa. Mówi się zatem w ten sposób o dziele literackim i wrażeniu realności, jakie daje ono czytelnikowi - może mu się bowiem zdawać, że w owej powieści musi tkwić fragment prawdziwego życia, że być może nie jest ona literaturą, a prawdziwym tekstem.

46 J.M. Goulemot, Praktyki literackie albo jawność życia prywatnego, dz. cyt., s. 453-454.

47 Watt pisze, że dzięki listom zastosowanym w powieści „mamy wgląd zarówno w myśli postaci, jak i we wnętrza ich domów”. I. Watt, Powieść a doświadczenie osobiste, dz. cyt., s. 206-207. 
samiał się z bohaterami, uczestniczył w ich emocjach, przeżywał ich rozterki, a nawet czasem odbywał wraz z nimi moralną edukację ${ }^{48}$. Jednocześnie odbiorcy nie myśleli raczej, że mają do czynienia z prawdziwymi listami, może tylko przez moment mieli takie wrażenie, zbyt dobrze jednak znali zabiegi ówczesnych pisarzy i konwencje powieściowe, aby wierzyć, że mają w ręku autentyczną korespondencję. Gra, jaką prowadził z nimi pisarz, podobała im się jednak, a listy wystarczająco mocno uwodziły jako obraz prawdziwego życia człowieka.

\section{Iluzjonizm}

Te spostrzeżenia przybliżają nas do zagadnienia iluzjonizmu, któremu warto się na koniec przyjrzeć, tym bardziej, że odnosi się ono zarówno do interesującego tu malarstwa, jak i powieści epistolarnej.

Iluzjonizm w sztuce jest zabiegiem mającym na celu włączenie przedstawienia w trójwymiarową przestrzeń, w której znajduje się widz, tak aby miał on poczucie, że ma do czynienia z przedmiotem rzeczywiście obecnym, a nie tylko przedstawionym. Obrazy wykorzystujące iluzjonizm prezentują umiejętności artysty potrafiącego doskonale realistycznie ukazać dany obiekt, ale wyrażają także naukowego ducha badania i demonstrowania - stąd zainteresowanie optyką oraz studia nad perspektywą i światłocieniem czy też ćwiczenia z anamorfozami i posługiwanie się camera obscura ${ }^{49}$. Samo przekonanie, że talent i kunszt mala-

48 „It seduced the reader into identifying with this character and sharing his or her emotions, becoming implicated, as it were, in the character's transgressive desires so as to undergo the same moral lesson in the course of the action". M. Franje, The Epistolary Novel..., dz. cyt., s. 17.

49 Zob. hasło illusionism w: Dictionary of Art, red. J. Turner, New York-London 1998, vol. XV, s. 134-142 oraz rozdział: Warunki powstania złudzenia, [w:] E. Gombrich, Sztuka i złudzenie, dz. cyt., s. 198-235. Warto zwrócić uwagę, że zainteresowanie sztuki holenderskiej iluzjonizmem, złudzeniami, a pośrednio nadanie szczególnego znaczenia zmysłowi wzroku, oku oraz procesowi widzenia wiąże się z rozwojem optyki zarówno w wymiarze teoretycznym, jak i praktycznym. Środowiska holenderskie przyswajały teorie i wyniki eksperymentów optycznych pochodzące z innych krajów europejskich, także same uczestniczyły w ich rozwoju. Nie poprzestawano jednak na poziomie teoretycznych rozważań (choć w Holandii rozwijała się prężnie optyka jako nauka, powstawały liczne traktaty, wzorniki i podręczniki w tym zakresie), ale używano ich w praktyce - była to praktyka malarska artystów, a także praktyka szlifowania szkła i wytwarzania przyrządów optycznych (soczewek, lunet, mikroskopów), z których Holandia słynęła. Stąd studia malarzy nad perspektywą i światłocieniem, czego przykładem np. specyficzne ćwiczenia $\mathrm{z}$ anamorfozami, wykorzystanie camera obscura czy też przedstawienia-złudzenia, w tym popularne trompe-l'œil i kasety perspektywiczne. Zob. rozdział Optyka, perspektywa, iluzja, [w:] A. Ziemba, Iluzja a realizm. Gra z widzem w sztuce holenderskiej 1580-1660, 
rza oraz cel sztuki objawiają się właśnie $\mathrm{w}$ doskonałym naśladowaniu natury, pochodzi ze starożytności, z ówczesnej myśli filozoficznej i przekazów źródłowych dotyczących malarstwa greckiego, a ponadto świadczą o tym zachowane malowidła rzymskie ${ }^{50}$. W XVII wieku koncepcja iluzjonizmu zachowała swą ważność: „Z jednej strony iluzja mimetyczna [np. realistyczne portrety, martwe natury, sceny rodzajowe], z drugiej iluzja fantazji [np. przedstawianie historii i alegorii] - oto bieguny siedemnastowiecznej teorii i sztuki" 51 . O celach malarstwa związanych z idealna imitacją i tworzeniem złudzeń pisali też sami XVII-wieczni holenderscy malarze i teoretycy ${ }^{52}$. Twórcom chodziło o podkreślenie roli malarstwa jako wiernego naśladownictwa, niemal kopii rzeczywistości, odzwierciedlenia obyczajów i odbicia prawdy, co miało oczarowywać zarówno umysły odbiorców, jak i uwodzić oraz zarazem zwodzić ich zmysły, wzbudzać namiętności, a nawet pożądanie względem sztuki. Poza tym obrazy bardzo często przekazywały dodatkowo określoną myśl, najczęściej pouczały lub ostrzegały, zawierały przekaz o charakterze umoralniającym, a enigmatyczność i dwuznaczność oraz przyjemność płynąca z odsłaniania znaczeń były charakterystyczne dla malarstwa holenderskiego. Można mówić o obecności w nim dwóch rodzajów sztuki zwodzenia: przyjemna zwodniczość doskonałej imitacji rzeczywistości oraz zwodniczość stworzona przez ukryte prawdziwe znaczenie przedstawionej sceny ${ }^{53}$, obie miały uczyć oraz zachwycać i bawić. Zwodzenie i uwodzenie za pomocą iluzjonistyczności i aluzyjności stanowią wyjaśnienie właściwości i celu obrazu. Odnosi się to przede wszystkim do malarstwa holenderskiego XVII wieku, choć omawiane w pracy dzieła holenderskie nie należą do ścisłej grupy trompe-l'œil. Wydaje się, że można zastosować owe określenia także do sztuki francuskiej XVIII wieku, która nie jest tak prze-

Warszawa 2005, s. 36-42 oraz M. Kemp, The Science of Art: Optical Themes in Western Art from Brunelleschi to Seurat, New Haven-London 1990.

50 Najciekawszych przykładów przedstawień malarskich doskonale realistycznych, idealnie naśladujących rzeczywistość i iluzyjnie łudzących oko dostarcza Historia naturalis Pliniusza Starszego z I wieku, w której bohaterami historii i anegdot są Apelles, Zeuksis i Parrozjos, a także Eikones Flawiusza Filostrata z III wieku.

${ }^{51}$ A. Ziemba, Iluzja a realizm..., dz. cyt., s. 33.

52 Philips Angel twierdził: „Jesteśmy naśladowcami życia [We are imitators of life]”. Cyt. za: E. de Jongh, To instruct and delight, [w:] tegoż, Questions of meaning. Theme and motif in Dutch seventeenth-century painting, Leiden 2000, s. 87. Holenderski malarz i teoretyk Samuel van Hoogstraeten pisał: „obraz jest niczym zwierciadło natury, które każe jawić się rzeczom, jakie nie istnieją, i które oszukuje w sposób przyjemny i olśniewający". Cyt. za: A. Ziemba, Iluzja a realizm..., dz. cyt., s. 35.

53 E. de Jongh, To instruct and delight, dz. cyt., s. 90-92. Wiedzy o możliwych znaczeniach danego przedstawienia dostarczały m.in. bardzo popularne wówczas książki emblematyczne, np. dzieła Jacoba Catsa. 
pełniona elementami iluzjonistycznymi jak sztuka północna, ale na pewno charakteryzuje ją aluzyjność i chęć uwodzenia.

XVII-wieczna sztuka holenderska przejawiała też szczególne umiłowanie dla realizmu i rzeczywistości, w rezultacie obecny jest w niej zarówno realizm, jak i iluzja. O ile ten pierwszy można stosunkowo krótko scharakteryzować jako umiłowanie wiernego odtwarzania codziennej rzeczywistości, o tyle zagadnienie iluzji rysuje się w sposób bardziej złożony i można mówić o różnego rodzaju złudzeniach. Antoni Ziemba, pisząc o malarstwie holenderskim Złotego Wieku (1580-1660), wyróżnił dwa porządki, na których poziomie można mówić o złudzeniach - podmiotowy i przedmiotowy. Pierwszy dotyczy widza i jego odbioru dzieła sztuki, dialogu między nim a dziełem, które manipuluje przestrzenią, wykorzystuje triki optyczne po to, aby przełamać barierę powierzchni obrazu i w rezultacie wyjść do widza ${ }^{54}$. Drugi wiąże się z samym obrazem, który chce udawać, że nie naśladuje i nie przedstawia innych przedmiotów, ale jest tym innym, prawdziwym przedmiotem. Chodzi tu o „dzieła, które udają, że nie są obrazem, a "naprawdę" tym, co przedstawiają”55, które chcą przekroczyć granicę między obrazem a światem

54 Toczy się tu gra z widzem, ma miejsce dialog widza i obrazu, wciąganie odbiorcy do obrazu i jednocześnie wysuwanie się obrazu do niego, np. poprzez 1) wprowadzenie złudzeń optycznych i zabaw przestrzenią (wysuwanie przed lico obrazu różnych elementów kompozycji - wychylanie się postaci, wysuwanie ręki, umieszczanie postaci w kadrze drzwi lub okna); 2) wykorzystanie motywu ramy lub parapetu (na które „nachodzi” namalowana postać) oraz kotary (która „przysłania” obraz); 3) tworzenie sugestii „mówiącego obrazu" (postacie zwracają się do widza wzrokiem, gestem, mają otwarte usta, jakby mówiły do odbiorcy); 4) wizualne niedopowiedzenie, które widz sobie dopowiada, widzi to, co niewidoczne, ale czego można się domyślić (np. gdy część obrazu „zakrywa” namalowana kotara). Zob. A. Ziemba, Iluzja a realizm..., dz. cyt., s. 14-15 oraz cały rozdział Przełamać barierę $\mathrm{w}$ tejże książce. O wizualnych trikach i zabiegach $\mathrm{w}$ malarstwie zob. też: V.I. Stoichita, L'invenzione del quadro. Arte, artefici e artifici nella pictura europea, przeł. di B. Sforza, Milano 2004.

${ }^{55}$ A. Ziemba, Iluzja a realizm..., dz. cyt., s. 212. Zob. też rozważania o ramie i granicy w: B. Uspieński, Strukturalna wspólnota różnych rodzajów sztuki (na przykładzie malarstwa i literatury), [w:] Semiotyka kultury, wybór i oprac. E. Janus i M.R. Mayenowa, Warszawa 1975, s. 211-242. Badacz podkreślał, że można obserwować „dążenie do naruszania granicy przestrzeni artystycznej (...) powoduje je dążenie do maksymalnego zbliżenia świata przedstawionego do świata rzeczywistego, by uzyskać możliwie największy realizm (prawdopodobieństwo obrazu)” po to, by sztuka stała się „prawdziwa” jak rzeczywistość. Jednocześnie stwierdzał: „aby zobaczyć świat jako świat znaków, konieczne jest (chociaż nie zawsze wystarczające) przede wszystkim oznaczenie granic" (tamże, s. 222-223), które są tworzone przez same fizyczne ramy obrazu lub sygnaturę malarza umieszczoną na płótnie, oznaczają one granice między światem zewnętrznym a wewnętrznym obrazu. W literaturze są to początki i zakończenia, wstępy, prologi, epilogi, posłowia, pojawienie się nagle w zakończeniu narratora pierwszoosobowego lub zwrotu do czytelnika, wprowadzenie różnych punktów widzenia, ocen, języków etc. Wkracza w ten sposób do dzieł świat 
rzeczywistym i widzem ${ }^{56}$. Specyfiką takich przedstawień jest to, że choć podają się za coś innego, za zwykłe obiekty znane z codziennego życia, to $\mathrm{w}$ istocie nie chcą być za takie uznane. Właśnie rozpoznanie w nich obrazu danego przedmiotu i uznanie doskonałości iluzjonistycznego przedstawienia, a nie ich utożsamienie $\mathrm{z}$ danym przedmiotem jest źródłem zachwytu widza, a celem malarza.

Dialog między widzem a obrazem odbywa się nie tylko na poziomie formalnym, wizualnym (wabienie realizmem i łudzenie za pomocą iluzji), lecz także na poziomie treściowym, ikonograficznym - chce się widza zainteresować, zaskoczyć, a nawet wzbudzić podniecenie, dlatego podejmuje się tematy intrygujące, pobudzające zmysły oraz wyobraźnię. Do tego typu obrazów należą np. takie, które coś skrywają, które przekazują dodatkowo pewne treści i konteksty, wymagające jednak odkrycia i dopowiedzenia przez samego widza. Elementy takiego działania znajdujemy w omawianych holenderskich, a do pewnego stopnia także francuskich obrazach rodzajowych, które ukazują postacie, gesty, czynności i przedmioty pozwalające dointerpretować scenę, lepiej i pełniej ją zrozumieć. Jeśli chodzi o powieści epistolarne, to nie przekazują one właściwie dodatkowych informacji i przesłań, które wymagają dostrzeżenia i odsłonięcia, a które poszerzają odbiór dzieła, pozwalają je w pełni zrozumieć. Przesłanie moralne i dydaktyczne, bo takie najczęściej występuje, jest w zasadzie wyrażone w sposób jasny i bezpośredni, wynika z postaw i działań postaci, ponadto jest najczęściej wprost określone $\mathrm{w}$ przedmowie rzekomego wydawcy, a de facto autora. Z kolei zarówno w wypadku analizowanego malarstwa, jak i literatury spotykamy realizm przejawiający się $\mathrm{w}$ wiernym naśladowaniu rzeczywistości $\mathrm{w}$ zakresie prawdopodobieństwa ukazanego świata oraz realności fizycznej przedstawionych postaci, ich otoczenia domowego, społecznego i przyrodniczego (widocznych szczególnie na obrazach ${ }^{57}$ ), a ponadto ich auten-

względem nich zewnętrzny albo obserwujemy przejścia od zewnętrznej do wewnętrznej pozycji widza i autora. Uspieński zwracał więc uwagę na problemy jak najbardziej istotne przy omawianiu zagadnienia iluzjonizmu w malarstwie i literaturze.

56 Tak pragną być odbierane niektóre trompe-l'œil - np. przedstawiające wnęki i szafki z różnymi przedmiotami; quodlibety ukazujące zasobniki z listami, kopertami, dokumentami oraz rozmaitymi zwyczajnymi, drobnymi i nieuporządkowanymi rzeczami (jak pióro, lak, wstążka); obrazy, które pokazuja inny obraz, np. słynna Sztaluga z ok. 1670 roku Corneliusa Norbertusa Gijsbrechtsa; wreszcie dzieła przedstawiające bukiet kwiatów, kosz z owocami lub zwierzęta. Do tej kategorii złudzeń malarskich należą także malowidła udające, że należą do innego gatunku i posługują się innymi materiałami i technikami niż jest w rzeczywistości (obrazy, które imitują rzeźby, rysunki, grafiki), obrazy wyglądające jak mapy i vice versa czy też obrazy w tzw. kasetach perspektywicznych. Zob. A. Ziemba, Iluzja a realizm..., dz. cyt., s. 15-16 oraz 210-238.

57 Trzeba zdać sobie sprawę z tego, że XVII-wieczne holenderskie sceny rodzajowe powstawały w wyniku świadomych decyzji planującego obraz malarza - nie jako po prostu

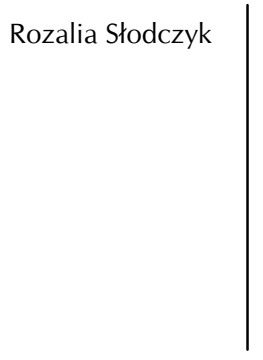


tyczności psychicznej, prawdziwości ich charakteru, uczuć, a także prywatnego i intymnego życia (obecnych zwłaszcza w literaturze).

Jeśli natomiast zastanowimy się nad kwestią iluzji, to dojdziemy do wniosku, że do analizowanego tu malarstwa holenderskiego odnieść możemy pojęcie podmiotowego poziomu złudzeń (w omawianej sztuce francuskiej iluzji i iluzjonizmu właściwie nie znajdujemy, ograniczamy się więc tutaj do analizy sztuki holenderskiej). Obrazy te nie należą do typu trompe-l'œil w całym tego słowa znaczeniu, tzn. nie chcą podawać się za przedmioty, które przedstawiają, nie chcą łudzić doskonałością iluzjonistycznego przedstawienia, ale podejmują raczej dialog $\mathrm{z}$ widzem, chcą wyjść do niego, złączyć swoją przestrzeń z przestrzenią, w której znajduje się odbiorca, dlatego wykorzystują kotary, lustra bądź „wizualne niedopowiadanie”. Powieści w listach moglibyśmy z kolei włączyć do poziomu przedmiotowego iluzji, utwory te bowiem podają się za coś innego niż są w rzeczywistości, tzn. chcą łudzić czytelnika, że ma do czynienia z prawdziwą korespondencją prywatnych osób i prawdziwą historią autentycznych ludzi, że nie czyta książki, ale dokument, że nie obcuje z fikcją, ale z rzeczywistością. W tym celu powieści wykorzystały list, zatem gatunek użytkowy, a nie literacki, i tym samym włączyły kawałek rzeczywistości do literatury. Czytelnik może odnosić wrażenie, że czyta czyjąś prywatną korespondencję, widzowi obrazu zaś może się co najwyżej wydawać, że namalowane postacie, wnętrza i przedmioty są bardzo realne oraz że tak zapewne wyglądały w rzeczywistości, ale nie myśli, że są one realne. Sądzić można zatem, że pod tym względem powieści w listach mogły bardziej łudzić niż malarstwo, choć jednocześnie czytelnicy nie myśleli raczej, że czytają czyjąś autentyczną korespondencję, byli obeznani z panującymi konwencjami i znali „chwyty” pisarzy, o czym była już mowa.

Między autorem a czytelnikiem powieści w listach zostaje zawiązany dialog, toczy się gra przypominająca tę mającą miejsce między malarzem a widzem obrazu w typie trompe-l'œil: obu twórcom chodzi o łudzenie odbiorcy, sprawianie, żeby myślał, a chociaż przez chwilę pomyślał, że ma do czynienia z czymś rzeczywistym. Odbiorca w obu przypadkach raczej nie trwa w złudzeniu, że oto ma przed sobą jakiś fragment realne-

dzieła utrwalające konkretny moment, konkretne wnętrze, konkretne osoby, ale przedstawiające pewne typy i charaktery. Jednak ów przedstawiony świat był wiernym naśladownictwem elementów i sytuacji z codziennej rzeczywistości: „Genre pieces are scenes that look to us as if they were taken from everyday life, depictions of situations as they might have been, but in the fact they were composed in artist's studio. They are never spontaneous records of a moment (...) painters set out first and foremost to be realistic not only in their forms and imitations on materials, but also in the depiction of the situation to be portrayed". E. de Jongh, To instruct and delight, dz. cyt., s. 85-86. 
go świata, ale chyba chociaż przez moment tak odbierał dzieło. Kiedy ta chwila minęła, zaczął się cieszyć samym dziełem, właśnie dlatego, że ono tak dobrze imituje i udaje prawdziwe twory natury albo człowieka. Taki też jest cel twórcy - sprawić, żeby czytelnik lub widz uległ złudzeniu, ale, ponieważ niejako z góry wiadomo, że iluzja, nawet jeśli zaistnieje, nie będzie trwała długo, chodzi o uwiedzenie odbiorcy urokiem dzieła, skłonienie go do podziwiania samego artysty, jego talentu i kunsztu. Trompe-l'œil, malarskie bądź literackie, nie tyle lub nie tylko chce łudzić i udawać, że jest czymś innym niż jest faktycznie (tzn., że nie jest obrazem lub literatura, ale danym przedmiotem albo autentycznym tekstem zwykłego człowieka), ile chce, aby je podziwiać, z przyjemnością je odbierać, nawet jeśli się wie, a właściwie właśnie dlatego, że się wie, iż jest ono fikcyjne, sztuczne i stworzone przez człowieka. Granice między rzeczywistością a fikcją zostają niemal zatarte, ale istotne jest znaczenie owego niemal - autor niby udaje, że go w ogóle nie ma, że ma się do czynienia z czymś prawdziwym, a nie wytworzonym na wzór prawdziwego, ale jednak chce, żeby w nim rozpoznano twórcę owego kunsztownie i subtelnie zwodzącego tworu. Wydaje się, że takie balansowanie na granicy stanowi istotę gry z odbiorcą i czyni ją emocjonującą. Nie ma się tu bowiem do czynienia ani ze zwykłym przedstawieniem lub zwykłą książ$\mathrm{kac}$, ani z normalnymi listami lub postaciami i przedmiotami, ale pozostaje się niejako zawieszonym - nie ma się pewności ani jasności w kwestii statusu obiektów, z którymi się obcuje. W odbiorze tego typu dzieł aktywny i świadomy jest zarówno twórca, jak i odbiorca, prowadzą oni grę, która przynosi im przyjemność i satysfakcję.

Jak mogliśmy zobaczyć, istnieje ścisły związek między powieściami epistolarnymi oraz malarstwem wykorzystującym motyw listu. Fascynacja listem przez zwykłych ludzi, a także literaturę i sztukę miała miejsce na tym samym obszarze i w tym samym czasie, a związana była z kontekstem kulturowym i społecznym. Listy wkroczyły do literatury i sztuki z obszaru piśmiennictwa użytkowego, wiązały się z epistolografią prywatną, więc ich tematyka dotyczyła życia codziennego, spraw osobistych i uczuć - najczęściej miłości. List w powieści epistolarnej stał się głównym elementem budowy utworu, wpłynął nie tylko na jego formę, lecz także na treść. $\mathrm{Z}$ kolei $\mathrm{w}$ obrazach był jednym z przedstawionych przedmiotów, często jednak najistotniejszym dla tematu. W obu wypadkach miał więc podstawowe znaczenie dla dzieła. W malarstwie pojawił się jako istotny motyw, wokół którego tematycznie i kompozycyjnie budowana była cała scena. Jeśli nie znajdował się w centrum uwagi, jak to mogliśmy obserwować w niektórych obrazach francuskich, to i tak jego „odkrycie” pomaga znacząco w zrozumieniu sceny, w charakterystyce postaci i jej otoczenia. List został zatem wykorzystany w malarstwie 
zgodnie z możliwościami tej dziedziny - jako efekt wizualnego naśladownictwa pewnego przedmiotu realnego, z którym wiąże się wykonywanie konkretnych czynności, ale też uwzględniona została jego funkcja nośnika określonych treści, dlatego mógł wywoływać określone emocje i zachowania u ukazanych bohaterów. W literaturze zaś list został użyty zarówno ze względu na swe właściwości formalne, jak i treściowe, tzn. wykorzystano kompozycję oraz styl wypowiedzi listownej i za jej pomoca przekazywano cała fabułe powieści. Jako obiekt wizualny list wykorzystano tu natomiast tylko pośrednio, głównie w wyniku naśladownictwa jego formy, i w ograniczonym stopniu ${ }^{58}$. Wreszcie list miał szczególne znaczenie ze względu na możliwość wprowadzania aluzji autentyczności oraz iluzyjności. Wszystko to wpływa na podobieństwo w zakresie ekspresji omawianych dzieł literatury i sztuki, ich oddziaływania na odbiorców. Aktywny i świadomy jest tu zarówno twórca, jak i czytelnik lub widz, prowadzą oni nie tylko dialog, ale i grę, a odbiorcy są zainteresowani tymi powieściami i obrazami, ponieważ kontakt $\mathrm{z}$ nimi jest dla nich atrakcyjny, daje przyjemność i satysfakcję. Dzieje się tak dlatego, że przedstawiony zostaje $\mathrm{w}$ przekonujący sposób prywatny, a nawet wewnętrzny świat postaci, a ponadto obrazy kuszą pięknem i realnością, a powieści łudzą prawdziwością. W rezultacie odbiorca wciągany jest do środka dzieła.

58 Naśladownictwo dotyczy budowy listu i faktu, że jest on zapisem jakiejś wypowiedzi, natomiast nie wiąże się $\mathrm{z}$ oddaniem charakteru pisma, właściwości materiału, na którym jest ono umieszczone oraz „normalnego” wyglądu - rozmiary listu, ślad po laku albo pieczęci etc. 
